\title{
First report and damage description of Calodesma collaris (Drury, 1782) (Lepidoptera: Erebidae) caterpillars on Aechmea winkleri Reitz, 1975 (Bromeliaceae)
}

\author{
Beatriz Timm Rutz ${ }^{1}$ (D), Vinícius Soares Sturza ${ }^{2 *}$ (D), Gustavo Heiden ${ }^{3}$ (D), \\ Dori Edson $\mathrm{Nava}^{3}$ (D)
}

${ }^{1}$ Universidade Federal de Pelotas, Instituto de Biologia, Capão do Leão, RS, Brasil.

${ }^{2}$ Universidade Federal de Pelotas, Programa de Pós-Graduação em Fitossanidade, Capão do Leão, RS, Brasil.

${ }^{3}$ Embrapa Clima Temperado, Pelotas, RS, Brasil.

\section{A R T I C L E I N F O}

\section{Article history:}

Received 09 April 2020

Accepted 23 June 2020

Available online 07 August 2020

Associate Editor: Lucas Kaminski

\begin{abstract}
A B S T R A C T
We report for the first time the occurrence of Calodesma collaris (Drury, 1782) (Lepidoptera: Erebidae) caterpillars on Aechmea winkleri Reitz, 1975 (Bromeliaceae) and describe the damage it causes on these plants. The consumption of leaf tissue, accumulation of excrements and inhibition of inflorescence emission caused by larvae of $C$. collaris can result in plants of $A$. winkleri that are not suitable for ornamental or landscaping purposes.
\end{abstract}

\section{Keywords:}

Arctiinae

Bromeliads

Caterpillar

Pericopina

Landscaping

The commercial cultivation of native plants is a promising alternative for the conservation of threatened species. It diversifies the options in the market and generates an alternative source of income for growers, especially when it involves ornamentation and landscaping species (Heiden et al., 2006). The bromeliad Aechmea winkleri Reitz, 1975 (Bromeliaceae) is native from southern Brazil and endemic to the Rio Grande do Sul and Santa Catarina states (Forzza et al., 2015). This species is included in the red list of species at risk of extinction in Brazil ranked as "critically endangered" (Martinelli and Moraes, 2013). A. winkleri has leaves with serrate margins and prickles, a bipinnate inflorescence in the basal half, and a simple inflorescence at the apex. The latter has sessile flowers with red sepals and yellow petals (Goetze, 2010).

Many bromeliads have coriaceous leaves which are an inappropriate food to many insects (Albertoni et al., 2012). However, there still are specialized herbivorous insects that feed on these plants in natural conditions, but these associations are poorly documented (Magalhães et al., 2012). Lepidopteran species were recorded to damage bromeliads plants, such as Vriesea bituminosa Wawra (Bromeliaceae), damaged by larvae

\footnotetext{
* Corresponding author.

E-mail: vsturza27@yahoo.com.br (Vinícius S. Sturza).
}

of Epimorius suffusus Zeller, 1877 (Pyralidae) (Monteiro and Macedo, 2014) and Ananas comosus (L.) (Bromeliaceae) damaged by larvae of both Chrysodeixis includens (Walker, [1858]) (Noctuidae) and Sufetula anania (Crambidae) (Detoni et al., 2018; Solis et al., 2019). Also, larvae of Escalantiana estherae J.Y. Miller, 2019 (Castniidae) were collected on plants of Tillandsia prodigiosa (Lem.) Baker (González et al., 2019), and Geyeria decussata (Godart, 1824) (Castniidae) is associated with species of bromeliads (Albertoni et al., 2012).

During multiplication and cultivation, the frequency of plants attacked by herbivorous insects usually increases (Hoffmeister et al., 2016). This leads to losses in leaf area and visual depreciation, what makes the assessment and report of potential pests to become an important economic topic. This paper reports for the first time the occurrence of Calodesma collaris (Drury, 1782)(Lepidoptera: Erebidae) on $A$. winkleri and describe the damage caused on the plants.

Aechmea winkleriplants that were kept in a greenhouse at Embrapa Clima Temperado (ECT) in the municipality of Pelotas, in the state of Rio Grande do Sul (RS), Brazil were found with damage on the leaves and the presence of lepidopteran larvae in February, 2019. To identify the causes 
of the damage, the insects were captured with the aid of washes on the attacked plants, which stimulate an upward movement of the larvae. All the collected insects were transferred to the laboratory and kept in a cage $(50.0 \times 50.0 \times 40.0 \mathrm{~cm})$ with $A$. winkleri leaves and water until pupae and adults were obtained. The insects were kept under controlled conditions of temperature $\left(25 \pm 1^{\circ} \mathrm{C}\right)$, relative humidity $(70 \pm 15 \%)$, and photophase (12h). Plant identification was performed based on both the scientific collections of the ECT Herbarium and comparisons with the original description of the species (Reitz, 1975) and the type specimen deposited at HBR herbarium (Herbarium "Barbosa Rodrigues" in the municipality of Itajaí, in the state of Santa Catarina, Brazil).

Thirty-six adult insects were obtained and identified as $C$. collaris, ten of which were deposited at the Entomological Collection of Embrapa Clima Temperado. Additionaly, two couples were separated in order to obtain eggs. They were placed in a cage lined with paper and fed with a liquid solution (70\% honey $+30 \%$ distilled water). Fifteen eggs were obtained but no larvae hatched.

Male and female adults of $C$. collaris have similar black coloring and a wingspan of approximately $2.4 \mathrm{~cm}(\mathrm{n}=36)$. The forewings present a white drop-shaped mark and the hindwings have a narrow white border (Fig. 1A). The eggs are smooth, spherical, with an average size of $0.1 \mathrm{~mm}$ in diameter $(\mathrm{n}=15)$, and light green colored at the beginning of the embryonic development turning to a darker shade later on (Fig. 1B). The larvae bear gray hairs along the yellowish body $(\mathrm{n}=79)$ (Fig. 1C). Before pupation, the caterpillars cease feeding and build cocoons. The pupae present a brownish color and measure $1.4 \mathrm{~cm}$ in length ( $n=72$ ) (Figs. 1D-E).
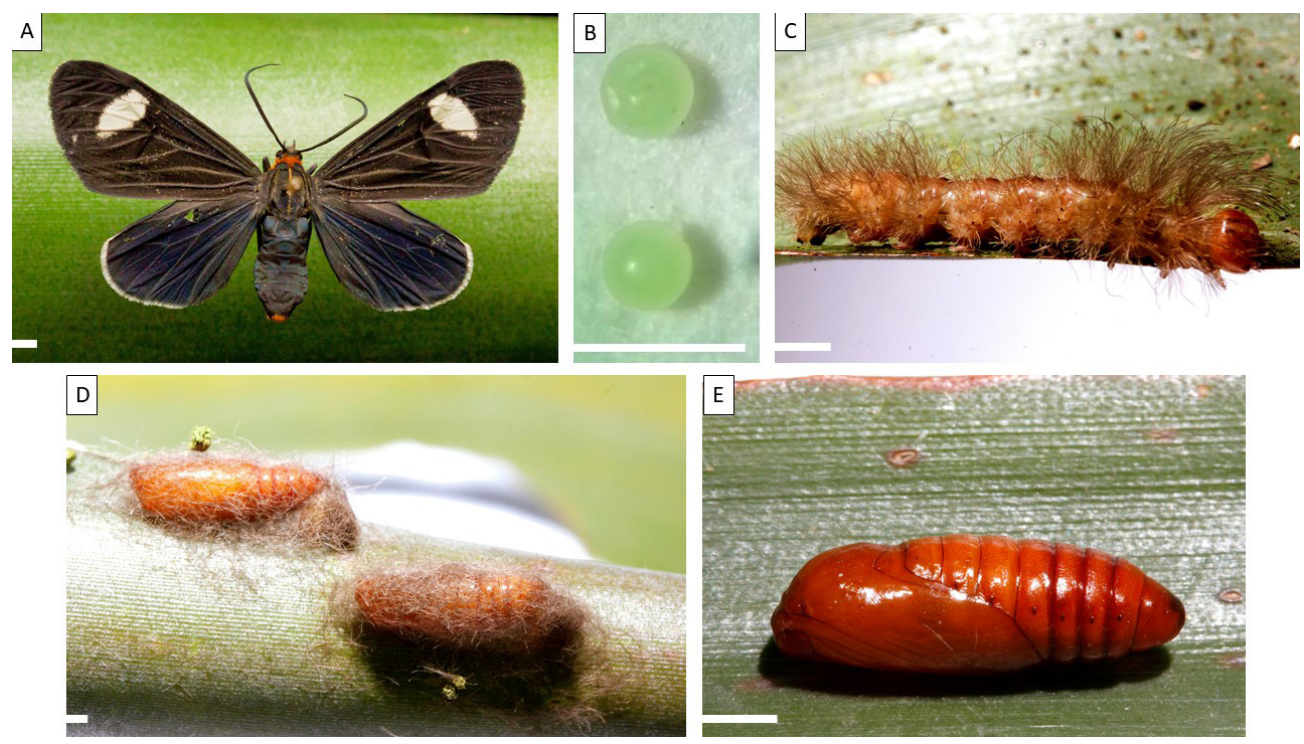

Figure 1 Adult (A), eggs (B), larva (C), cocoon (D), and pupa (E) of Calodesma collaris (Lepidoptera: Erebidae) obtained feeding on plants of Aechmea winkleri (Bromeliaceae). Scale: $2 \mathrm{~mm}$.
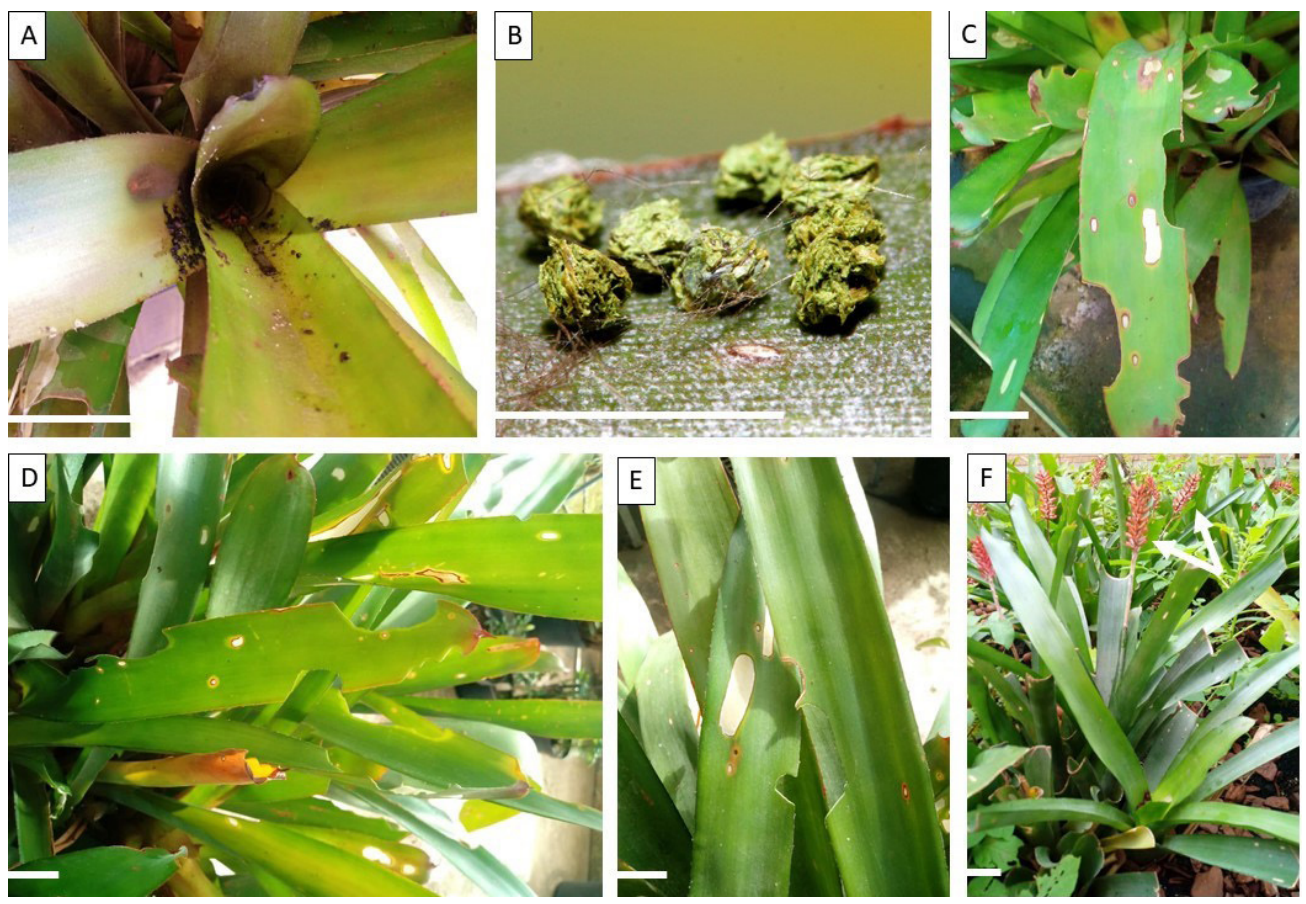

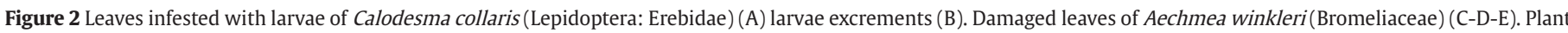
without damage displaying a health inflorescence (white arrows) $(F)$. Scale: $1 \mathrm{~cm}$. 
The larvae were found in the center of the injured plants and accumulation of excrements (frass) was observed (Figs. 2A-B). First-instar larvae caused small lesions in the developing leaf tissue and holes at the edge of leaves. The lesions increased as the leaves expanded (Figs. 2C-E). Moreover, higher infestations affected negatively the emission of the inflorescence, which is the main ornamental feature of this species. This increased visual depreciation compromises their marketability as either pot or landscaping plants when compared to non-attacked plants (Fig. 2F).

Despite not being quantified, it was visually observed that larvae of $C$. collaris also fed on leaves of other bromeliad species growing in the same facility, such as Bilbergia nutans $\mathrm{H}$. Wendl. (native), Ananas bracteatus (Lindl.) Schult \& Schult. (exotic), and $A$. comosus (exotic). This behavior corroborates with Ferro (2007) who mentions that C. collaris has been reported in several states in Brazil and, during the larval stage, can feed on leaves of different species for its nutrition. Therefore, considering economic losses and its range of hosts, this insect presents the potential to be a significant threat to native and exotic species of commercial bromeliads under cultivation.

\section{Acknowledgments}

Authors acknowledge Embrapa for financial support. The authors also thank Dr. Vitor Osmar Becker for the identification of C. collaris, Paulo Luiz Lanzetta Aguiar for photographing the insects and plants, and Felipe Andreazza for reviewing english writing.

\section{Funding}

To Embrapa Clima Temperado for granting the scholarship for Beatriz T. Rutz.

\section{Conflicts of interest}

The authors declare no conflicts of interest.

\section{Author contribution statement}

\author{
BTR - All stages. \\ VSS - Rearing in laboratory and writing. \\ $\mathrm{GH}$ - Plant identification and writing. \\ DEN - All stages.
}

\section{References}

Albertoni, F. F., Moraes, S. S., Steiner, J., Zillikens, A., 2012. Description of the pupa and redescription of the imagines of Geyeria decussata and their association with bromeliads in southern Brazil (Lepidoptera: Castniidae). Entomol. Gen. 34(1-2), 61-74. http://dx.doi.org/10.1127/ entom.gen/34/2012/61.
Detoni, A. M., Carvalho, S. L. C., Hoshino, A. T., Pastório, M. A., Schmidt, M. A. H., Menezes Junior, A. O., Androcioli, H. G., 2018. First report of Chrysodeixis includens (Walker, [1858]) (Lepidotera: Noctuidae) injurious to pineapple (Ananas comosus L.) (Bromeliaceae) in Brazil. Braz. J. Biol. 78 (4), 796-798. http://dx.doi.org/10.1590/15196984.174384.

Ferro, V. G., 2007. Diversidade de mariposas Arctiidae (Lepidoptera) do Cerrado. Doctoral of Science Thesis, Instituto de Ciências Biológicas, Universidade de Brasília. Available in: http://repositorio.unb.br/ handle/10482/8081 (accessed 30 April 2019).

Forzza, R. C., Costa, A., Siqueira Filho, J. A., Martinelli, G., Monteiro, R. F., Santos-Silva, F., Saraiva, D. P., Paixão-Souza, B., Louzada, R. B., Versieux, L., 2015. Bromeliaceae. Jardim Botânico do Rio de Janeiro, Rio de Janeiro. Available in: http://floradobrasil.jbrj.gov.br/jabot/ floradobrasil/FB5886 (accessed 30 April 2019).

Goetze, M., 2010. Filogeografia e diversidade genética de Aechmea caudata (Lindm.) e A. winkleri (Reitz) (Bromeliaceae): implicações taxanômicas. Master of Science Thesis, Instituto de Biociências, Universidade Federal do Rio Grande do Sul. Available in: http:// hdl.handle.net/10183/24075 (accessed 29 April 2019).

González, J. M., López G, B., Huerta P, J. P., Miller, J., 2019. A new genus of Castniinae (Lepidoptera: Castniidae) with comments on comparative morphology and bionomics of its assigned species. Zootaxa 4668 (1), 89--104. http://dx.doi.org/10.11646/zootaxa.4668.1.5.

Heiden, G., Barbieri, R. L., Stumpf, E. R. T., 2006. Considerações sobre o uso de plantas ornamentais nativas. Ornam. Hortic. 12, 2-7. https:// doi.org/10.14295/rbho.v12i1.60.

Hoffmeister, M., Wittköpper, N., Junker, R. R., 2016. Herbivore induced changes in flower scent and morphology affect the structure of flower-visitor networks but not plant reproduction. Oikos 125 (9), 1241-1249. http://dx.doi.org/10.1111/oik.02988.

Magalhães, N., Ferreira, L. B., Leitão, G., Mantovani, A., 2012. Efeitos da herbivoria foliar na bromélia Aechmea blanchetiana: estudo da alimentação seletiva pelo raspador Acentroptera pulchella. Acta Bot. Bras. 26 (4), 944-952. http://dx.doi.org/10.1590/S010233062012000400024.

Martinelli, G., Moraes, M. A., 2013. Livro vermelho da flora do Brasil, 1st ed. Instituto de Pesquisas, Jardim Botânico do Rio de Janeiro, Rio de Janeiro.

Monteiro, R. F., Macedo, M. V., 2014. First report on the diversity of insects trapped by a sticky exudate of the inflorescences of Vriesea bituminosa Wawra (Bromeliaceae: Tillandsioideae). Arthropod-Plant Interact. 8(6), 519-523. http://dx.doi.org/10.1007/s11829-014-9332-1.

Reitz, R., 1975. Encontro e reencontro de bromélias II Aechmea winkleri. Sellowia. 26, 63-67.

Solis, M. A., Hayden, J. E., Sanabria, F. V., Gonzalez, F., Ujueta, C. S., Gulbronson, C. J., 2019. A new species of SufetulaWalker (Lepidoptera: Crambidae) feeding on the roots of pineapple, Ananas comosus(L.) (Bromeliaceae), from Costa Rica. Proc. Entomol. Soc. Wash. 121 (3), 497-510. http://dx.doi.org/10.4289/0013-8797.121.3.497. 